\title{
THE CHARACTERISTICS, IMPACTS AND PERSPECTIVES IN GEOMORPHOLOGY AND PEDOLOGY IN POSTGRADUATE GEOGRAPHY
}

\author{
https://doi.org/10.4215/rm2019.e18012 \\ Edivaldo Lopes Thomaz a $^{*}$
}

(a) Dr. em Geografia, Prof. da Universidade Estadual do Centro Oeste, Guarapuava(PR), Brasil

ORCID: https://orcid.org/0000-0003-0246-5111. LATTES: http://lattes.cnpq.br/4660243356517448.

Article history:

Received 13 May, 2019 Accepted 31 May, 2019

Published 15 June, 2019

\section{(*) CORRESPONDING AUTHOR}

Address: UNICENTRO, Rua Simeão Camargo Varela de Sá, CEP: 85040400, Guarapuava (PR), Brasil. TEL (+55 42) 36298117.

E-mail: edilopes.thomaz@gmail.com

\begin{abstract}
Geomorphology and Pedology are found in several Geography postgraduate programs. However, there is no qualitative and quantitative evaluation of their role in each program. The objectives of this study were: a) to evaluate the impact of Physical Geography in Geography postgraduate of their role in each program. The objectives of this study were: a) to evaluate the impact of Physical Geography in Geography postgraduate
programs; b) to describe the scientific production in Geomorphology and Pedology within the scope of Geography programs in Brazil, and c) to evaluate the perspectives and risks for Geomorphology and Pedology in the context of the Brazilian Geography. The main conclusions were: 1) the correlation of the H-index, which is based on the impact of academic production, explains about $70 \%$ of the program score; 2) in the Southeast region's programs, Physical Geography had the lowest participation (20.8\%) in the H-index; 3) the South region stands out with the highest scientific production in Geomorphology $(36.2 \%)$ and Pedology $(39.4 \%) ; 4)$ the areas of Geomorphology and Pedology publish $50 \%$ of their articles in English, and 5) $67 \%$ of Pedology articles are published in English.
\end{abstract}

Keywords: CAPES, Brazilian Science, Epistemology, Endogeny

\section{Resumo / Resumen}

\section{CARACTERÍSTICAS, IMPACTO E PERSPECTIVAS EM GEOMORFOLOGIA E PEDOLOGIA}

A Geomorfologia e a Pedologia estão presentes em diversos programas de pós-graduação em Geografia. Mas, não existe uma avaliação qualitativa e quantitativa de seu papel em cada programa. Os objetivos deste trabalho foram a) avaliar o impacto da Geografia Física nos programas de pós-graduação em Geografia; b) caracterizar a produção científica em Geomorfologia e Pedologia no âmbito dos programas de Geografia no Brasil; c) avaliar as perspectivas e riscos para a Geomorfologia e Pedologia no contexto da Geografia Brasileira. A principais conclusôes foram: 1) a correlação do IH-programa, que tem como base o impacto da produção docente, explica em torno de $70 \%$ da nota do programa; 2 ) nos programas da região Sudeste a Geografia Física apresentou a menor participação $(20,8 \%)$ no IH-programa; 3 ) a região Sul se destaca com a maior produção científica em Geomorfologia (36,2\%) e em Pedologia (39,4\%); 4) as áreas de Geomorfologia e Pedologia, divulgam 50\% de seus artigos em língua inglesa; 5) na Pedologia $67 \%$ dos artigos são divulgados em inglês.

Palavras-chave: CAPES, Ciência Brasileira, Epistemologia, Endogenia

CARACTERÍSTICAS, IMPACTOS Y PERSPECTIVAS EN GEOMORFOLOGÍA Y PEDOLOGÍA EN GEOGRAFÍA DE POSTGRADO

La Geomorfología y la Pedología están presentes en diversos programas de postgrado en Geografía. Pero no hay evaluación cualitativa ycuantitativa de su papel en los programa. Los objetivos de este trabajo fueron a) evaluar el impacto de la Geografía Física en los programas depostgrado en Geografía; b) caracterizar la producción científica en Geomorfología y Pedología en el ámbito de los programas de Geografía en Brasil;c) evaluar las perspectivas y riesgos para la Geomorfología y Pedología en el contexto de la Geografía Brasileña. Las principales conclusiones fueron: 1) la correlación del IH-programa, que tiene como base el impacto de la producción docente, explica alrededor del $70 \%$ de la nota del programa; 2) en los programas dela región Sudeste la Geografía Física presentó la más baja participación (20,8\%) en el IH-programa; 3) la región Sur se destacó con la mayor producción científica en Geomorfología $(36,2 \%)$ y en Pedología $(39,4 \%) ; 4)$ en las áreas de Geomorfología y Pedología, fueron el $50 \%$ de sus artículos publicados en lenguaInglés; 5) en la Pedología el 67\% de los artículos han sido divulgados en inglés.

Palabras-clave: Palabras clave: CAPES, Ciencia Brasileña, Epistemología, Endogenia 


\section{INTRODUCTION}

Postgraduate studies have become a national phenomenon, particularly the expansion of postgraduate studies in Geography from the 2000s. The strong growth of postgraduate courses requires a constant evaluation of the quality and impact of the programs' scientific production. Thus, this essay addresses the following questions: Is there a relationship between the H-index (program impact) and the program score? What is the impact of Physical Geography in postgraduate programs? Is there an internationalization of production in Geomorphology and Pedology? Therefore, the objectives of this work are: a) to evaluate the impact of Physical Geography in postgraduate programs in Geography; b) to characterize the scientific production in Geomorphology and Pedology within the scope of Geography programs in Brazil, and c) to evaluate the perspectives and risks for Geomorphology and Pedology in the context of the Brazilian Geography.

The methodology analyzed the data produced by the DAV-Evaluation Board for Geography (Capes, 2016). Articles produced from 2005 to 2016 were evaluated, with an emphasis on the three main quotations from published scientists and scholars in Geomorphology and Pedology linked to Brazilian Geography Courses and Programs. The analyses were based on the construction of the H- index for Courses and Postgraduate Programs by the Coordination for the Field of Geography (2013-2016), through the Publish or Perish platform (Harzing, 2007), which uses the Google Scholar database.

The H-index of Courses and Programs were used to select the principal productions of professors with an $\mathrm{H}$-index equal to or greater than the course or program. These were scholars and works that were part of the construction of the H-index. In this way, the three main productions from 2005 to 2016 were evaluated, on the country and regional scale and by Higher Education Institutions (HEI).

The H-index of the programs had three primary outcomes. First, the relationship between $\mathrm{H}$-index and program scores $(\mathrm{p}$

\section{RESULTS AND DISCUSSION}

\section{The relationship between a program's $\mathrm{H}$-index and its concept}

A program's H-index records the productivity and impact that the program's scholars achieve during a particular period. This index was established to evaluate the field of Geography, considering the principal citations per program of authors with an $\mathrm{H}$-index equal to or higher than that of the program (IH Programa, 2005 to 2016).

There is a strong positive correlation between the H-index and the program score. Although this index only considers the impact of a professor's intellectual production, it can explain almost $70 \%$ of the concept obtained by the program (Figure 1). 


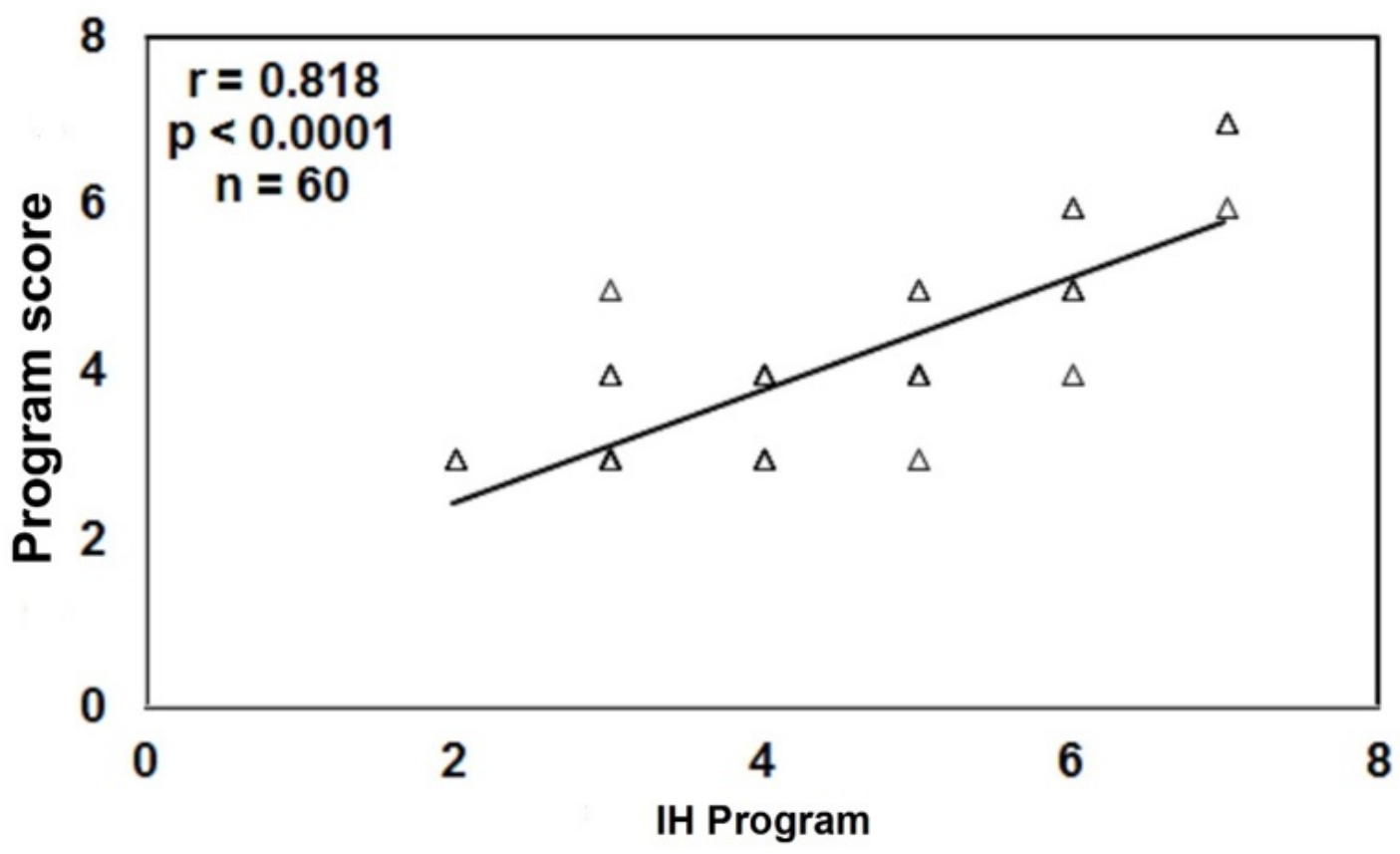

Figure 1. Correlation indicating the H-Index as an estimator of the program concept

A scholars' scientific production is, in fact, a good predictor of the program score. Scientific production is probably related to other important parameters for the program concept such as orientation, qualified production, and faculty, among others. Ultimately, professors with higher $\mathrm{H}$-index tend to have a positive impact on the program score.

\section{THE PARTICIPATION OF PHYSICAL GEOGRAPHY IN THE H-INDEX}

This analysis (Table 1) considered scholars with production in Physical Geography, who had participated in the composition of the H-index. That is, it measured the participation of the scientific production in Physical Geography in the impact of the H-index. Studies classified as environmental or geoprocessing were not considered.

In general, the scientific production of Physical Geography was significant in most programs. Also, to date, in some programs, the production in Physical Geography has not had a sufficient impact to be included in the H-index. Nevertheless, future studies may reach the level of citations required to compose this index. 


\begin{tabular}{|c|c|c|c|c|c|c|c|c|c|}
\hline Southeast & $\begin{array}{l}{ }^{1} \mathrm{PG} \\
(\%)\end{array}$ & Northeast & PG (\%) & South & PG (\%) & Center-West & PG (\%) & Norte & PG (\%) \\
\hline UNIMONTES & 0.0 & UESB & 0.0 & UFPEL & 33.3 & UFMT-CB & 20.0 & UFT & 16.7 \\
\hline UFRRJ & 0.0 & UEMA & 100.0 & FURGS & 60.0 & UFMT-RD & 75.0 & UNIR & 20.0 \\
\hline PUC-MG & 33.3 & UERN & 50.0 & UNIOESTE-MR & 40.0 & UFMS-TL & 42.8 & UFRR & 20.0 \\
\hline UERJ-SG & 20.0 & UVA & 33.3 & UNIOESTE-FB & 50.0 & UFMS-AQ & 20.0 & UFPA & 16.7 \\
\hline UFU-IT & 0.0 & FUFPI & 42.8 & UEPG & 33.3 & UFGD-MT & 0.0 & UFAM & 40.0 \\
\hline UFJF & 40.0 & UFAL & 66.6 & UEM & 28.6 & UNEMAT & 100.0 & & \\
\hline UFSJ & 66.6 & FUFSE & 0.0 & UEL & 14.3 & UFG-CT & 0.0 & & \\
\hline UFES & 25.0 & UFRN & 16.7 & UNICENTRO & 61.1 & UFG-JT & 50.0 & & \\
\hline UFF-GT & 20.0 & UECE & 20.0 & UFSM & 38.9 & UNB & 28.5 & & \\
\hline UNESP-RC & 30.0 & UFBA & 14.3 & UFSC & 50.0 & UFG & 37.5 & & \\
\hline PUC-RJ & 20.0 & UFPB & 20.0 & UFPR & 43.3 & & & & \\
\hline UERJ & 0.0 & UFPE & 60.0 & UFRGS & 19.0 & & & & \\
\hline UFU & 12.5 & UFC & 44.4 & & & & & & \\
\hline UFMG & 11.1 & & & & & & & & \\
\hline UNICAMP & 25.0 & & & & & & & & \\
\hline USP-GF & 33.3 & & & & & & & & \\
\hline UFF & 16.7 & & & & & & & & \\
\hline UNESP-PP & 12.5 & & & & & & & & \\
\hline UFRJ & 28.6 & & & & & & & & \\
\hline Region Average & 20.8 & & 36.0 & & 39.3 & & 37.4 & & 22.7 \\
\hline
\end{tabular}

Table 1. Participation of the scientific production of Physical Geography for the composition of the $\mathrm{H}$-index according to programs and regions

Note: 1 PG (Participation of Physical Geography in the composition of H-index in \%)

In $13 \%$ of the programs, Physical Geography did not participate in the composition of the $\mathrm{H}$-index. On the other hand, in $21 \%$ of the programs, the participation of Physical Geography was above $50 \%$. Scientific production in Physical Geography had participation ranging from $>10 \%$ to

Physical Geography programs in the Southeast region had the lowest participation $(20.8 \%)$ compared to the other regions, followed by the North region $(22.7 \%)$. The most substantial participation for the composition of the H-index occurred in the South (39.3\%), Central-West (37.4\%) and Northeast $(36.0 \%)$, respectively (Table 1$)$.

However, there is variability in the participation of Physical Geography within and between regions (Table 1), which raises some questions. In the case of the Southeast, at the oldest or most traditional courses (e.g., UNESP-PP, UFMG, UFF, and UFU), there is a trend of less participation of Physical Geography in the H-index. One reason may be the higher number of lines of research in these programs (diversity of areas), which may result in the distribution of participation in the H-index. Another possibility may be that some of these centers are, in reality, knowledge producers in Human Geography. Finally, although it may seem strange that a Physical Geography program (USP-GF) only has a 33\% impact in the composition of the $\mathrm{H}$-index, this occurred because many studies were classified as geoprocessing-environmental analyses.

There are fewer programs in the North, which also has the second lowest participation in the H-index for Physical Geography. Due to this region's characteristics (Brazilian agro-environmental border), the expectation was that Physical Geography would have more relevance in this parameter. However, that was not the case. The production of more integrative studies (e.g., environment, environmental analysis, and environmental geography) may predominate in these programs. At the UFAM, the participation of Physical Geography in the H-Index is similar to other regions (South, Northeast, and Center-West). Therefore, there is a need or opportunity to deepen studies in Physical Geography, as well as in physical-geographic disciplines (e.g. geomorphology and climatology).

In the Northeast and Central-West, the variability of the contribution of Physical Geography is remarkable. At first glance, it seems that in more recent programs, the contribution of Physical Geography is more significant. The impact in some programs is $100 \%$ while in others, the contribution is $0 \%$ (Table 1). Both cases cause concern, given that programs with fewer professors generally concentrate along two lines, one in Human Geography and the other in Physical Geography. Thus, it is desirable that both have a positive impact on the H-index.

In the South, the contribution of Physical Geography among the programs seems to be more homogeneous (above 30\%). Only at the UEL and UFRGS, is the contribution of Physical Geography to 
the H-Index well below the regional average; 2.7 and 2.0 times lower, respectively. In this region, Physical Geography has participated more in the composition of the H-index. One of the reasons for this may be the degree of internationalization of this field, as most of the studies are published in English and receive external quotations. This circumstance can also apply to cases in the other regions described above. On the other hand, in general, the other areas of Geography (e.g., Urban, Agrarian or Human Geography) do not yet have a similar impact on the H-index as the area of Physical Geography and also when compared to some programs in the Southeast region. This supposition will be examined in more detailed below when the productions in Geomorphology and Pedology are addressed.

In conclusion, Physical Geography currently has an important participation in the H-index. Scholars in this area have produced relevant studies that have an impact on postgraduate studies in Geography and, consequently, on Brazilian science. Overall, in the most recent programs, the production in Physical Geography seems to be higher in the participation in the H-index. Also, this impact is higher than that found in the oldest postgraduate centers located in the Southeast. Therefore, it is possible to discern the level of excellence existing in Physical Geography in several programs and Brazilian regions.

\section{Characteristics of scientific production in Geomorphology and
Pedology}

Firstly, it is not easy to separate a scientific production in Geomorphology or Pedology since both are strongly interdependent, especially when studies are carried out in the field. Throughout the history of these sciences, it is clear that this interdependence between pedo-geomorphology is inseparable in the study of forms, soil and surface processes (Milne, 1935; Conacher and Dalrymple, 1977; Gerrard, 1992). Despite these difficulties, this research separated the productions in Geomorphology and Pedology, even with the risk of both being present in the studies.

There were 94 articles classified as belonging to Geomorphology (58) and Pedology (36) (Table 2). Production in Geomorphology (61.7\%) was superior to Pedology $(38.3 \%)$. Of this total, $51 \%$ of the articles were written in Portuguese and 49\% in English. However, when considering production within the area, the situation is different. Scholars who publish Geomorphology articles primarily write in Portuguese (62\%), and the rest in English (38\%). In contrast, the majority of Pedology articles are written in English (67\%), and the remainder are in Portuguese (33\%).

In general, the articles written in English (19 citations / articles) and those written in Portuguese (14 cit / art) have the same citation rate ( $>0.10)$. In Geomorphology the citation of articles in English (14 cit / art) and Portuguese (15 cit / art), also shows no difference ( $p>0.10)$. In contrast, Pedology articles written in English (21 cit / art) receive twice as many citations as those written in Portuguese (11 cit / art) (p 0.10). Finally, authors with publications in English have a slightly higher H-index (H-index 7) than those who publish in Portuguese (H-index 6) (p

The periodicals divulging scientific production (Geomorphology and Pedology) are quite diverse. However, some scientific journals publish issues more frequently (Figure 2). In this case, it is evident that the dissemination occurs both in national Geography journals and in the specializations mentioned above. However, the higher frequency of publications in specialized journals prevails. In addition, when the publication is English, the international journals of high impact in the area of Physical Geography (Geomorphology and Pedology) are selected, for example, Geomorphology and Catena (Figure 2). 


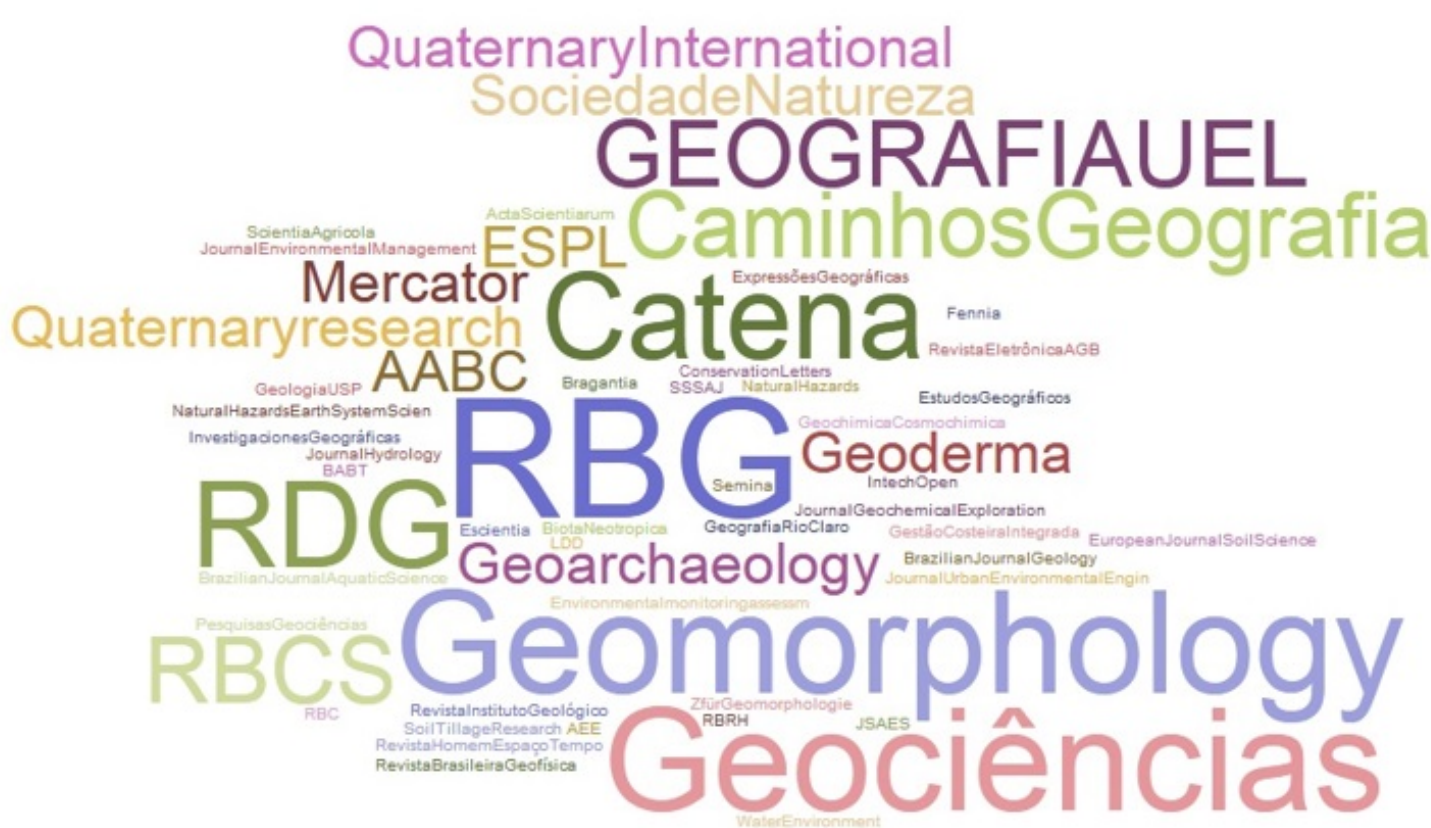

Figure 2. Periodicals where the articles in Geomorphology and Pedology are published

Note: A list of journals with more than one article published; aabc (

Annals of Brazilian Academy of Sciences), espl (Earth Surface Processes and Landforms); rbcs ( Brazilian Journal of Soil Science), rbg (Brazilian Journal of Geomorphology), $\operatorname{rdg}$ (Journal of the Department of Geography-USP).

Undoubtedly, the Geomorphology and Pedology professors are mostly publishing outside the classic and general Geography periodicals. There are probably around 150 Geography journals, which results in an average of more than two journals per Geography program. Besides, Geography has a tradition of periodicals from departments, postgraduate studies, and even laboratory or research groups. This tradition provides many journals for researchers in the field. So, why have Physical Geography scholars sought specialized journals to disseminate their research? It is a fact that Brazil has an escalation of periodicals, estimated at more than 5,000. Thus, publishing in national journals may isolate part of Brazilian science or generate knowledge islands (Pierro, 2013).

The same question was also posed 20 years ago in the UK by the editors of the Transactions of the Institute of British Geographers: where have all physical geographers gone? (Agnew and Spencer, 1999). The editors were concerned, as less than $10 \%$ of the articles submitted to the journal were classified as Physical Geography. One of the explanations for the low submission rates was that physical geographers were more specialized and closer to the environmental sciences. Therefore, when publishing in Geographic periodicals physical geographers would have less recognition and visibility (Agnew and Spencer, 1999).

In fact, since the 1990s, physical geography has undergone a restructuring of themes (e.g., sustainable development, urban regeneration, disaster management, risk analysis, and impact assessment, among others) (Gregory et al., 2002). These themes adhere to Geography journals. Other Geography journals (Annals of the Association of American Geographers and Australian Geographer), also verified a fall in the rate of publication of Physical Geography articles (Gregory et al., 2002). Also, physical geographers, especially the UK, have consolidated journals for circulation in the field: Earth Surface Processes and Landforms, Hydrological Processes, The Holocene, Journal of Quaternary Science, International Journal of Climatology, and Journal of Biogeography (Gregory et al., 2002).

What is happening in Brazilian Physical Geography has some similarities to the United Kingdom, but with some peculiarities. One resemblance is the attempt to disseminate research in high-impact consolidated journals, with greater visibility and peer recognition. Undeniably, at present, Geography journals in Brazil do not offer these possibilities. One of the particularities was the creation of 
specialized journals in the last decades: Brazilian Journal of Geomorphology, Brazilian Journal of Climatology and Brazilian Journal of Physical Geography. This has channeled many articles to specialist journals. However, these journals primarily publish articles in Portuguese, leaving them open to similar criticisms as the Geography periodicals, especially regarding the impact and visibility of investigations in Physical Geography.

Even in this scenario of islands of knowledge in Brazil, there is a surprisingly robust internationalization of Geomorphology and Pedology linked to Geography programs. However, there is still a long way to go, because the community of physical geographers is small, and scientific production does not have a desirable international impact. Between 2001 and 2005, Brazil's scientific production in geomorphology corresponded to $1.3 \%$ of the world total (Mendes and Salgado, 2008).

Furthermore, Geomorphology and Pedology has a particular regional asymmetry (Table 2). Within the national context, production in these areas is minimal in the North, followed by the Center-West. The Southeast region has a balanced production. Meanwhile, the South region stands out in production in both areas (Table 2). It is also necessary to consider that there are 12 programs in the South, compared with 19 in the Southeast. The program of Human Geography of the USP was not considered.

\begin{tabular}{lllllll}
\hline & \multicolumn{5}{c}{ Brazilian regions } \\
\cline { 2 - 7 } Parameters evaluated: & Center-West & Northeast & North & Southeast & South & Total \\
\hline Production in Geomorphology & 8.0 & 11.0 & 3.0 & 15.0 & 21.0 & 58.0 \\
Production in Geomorphology (\%) & $\mathbf{1 3 . 8}$ & $\mathbf{1 9 . 0}$ & $\mathbf{5 . 2}$ & $\mathbf{2 5 . 9}$ & $\mathbf{3 6 . 2}$ & $\mathbf{1 0 0 . 0}$ \\
\hline Production in Pedology & 4.0 & 7.0 & 0.0 & 9.0 & 16.0 & 36.0 \\
Production in Pedology (\%) & $\mathbf{1 1 . 1}$ & $\mathbf{1 9 . 4}$ & $\mathbf{0 . 0}$ & $\mathbf{2 5 . 0}$ & $\mathbf{4 4 . 4}$ & $\mathbf{1 0 0 . 0}$ \\
\hline Total production in Geomorphology and Pedology & 12.0 & 18.0 & 3.0 & 24.0 & 37.0 & 94.0 \\
Production in Geomorphology and Pedology (\%) & $\mathbf{1 2 . 8}$ & $\mathbf{1 9 . 1}$ & $\mathbf{3 . 2}$ & $\mathbf{2 5 . 5}$ & $\mathbf{3 9 . 4}$ & $\mathbf{1 0 0 . 0}$ \\
\hline
\end{tabular}

Table 2. Production in Geomorphology and Pedology by Brazilian regions

\section{Characteristics of the production in Geomorphology}

Scientific production in Geomorphology in Brazil, as well as the most productive subareas and producing centers, have been regularly evaluated in recent years (Salgado et al., 2008; De Oliveira and Salgado, 2013; Salgado and Limoeiro, 2017). The authors have evaluated national and international production. Therefore, in this study, there will only be a critical reference to previous studies, since they deal with the same universe of analysis, making another assessment redundant. However, the themes in Pedology will be evaluated more closely.

The universe of evaluation of the mentioned authors' production in Geomorphology between 2001 and 2015 were the following journals: 1) Brazilian Journal of Geomorphology (Brazilian Union of Geomorphology); 2) Geomorphology (International Association of Geomorphology); 3) Earth Surface Processes and Landforms (British Union of Geomorphology); and 4) Zeitschrift für Geomorphologie (German Association of Geomorphologists).

Between 2001-2005, the production in Fluvial Geomorphology was the most significant, both nationally $(25.6 \%)$ and internationally $(50 \%)$. On the national level, coastal geomorphology (16.7\%) was also noteworthy in the period evaluated. National production in geomorphology was highest in São Paulo state $(36.6 \%)$, followed by the states of Rio de Janeiro $(23.3 \%)$ and Parana (18.3\%). Eight research centers in the Southeast were responsible for $74 \%$ of the national production in Geomorphology. Concerning international production in the same period, the states of Goias (25\%), Parana (20.8\%), and Minas Gerais (16.6\%) had the highest production. On the other hand, the international production of SP $(12.5 \%)$ and RJ $(8.3 \%)$ was much lower than their national production. Brazil's global production in Geomorphology during this period was 1.6\% (Salgado et al., 2008).

Between 2006-2010, there was a thematic alteration in geomorphological production at the national level; slope processes (24\%), followed by fluvial geomorphology $(21.6 \%)$ had the highest 
production. However, in the international sphere, there was the growth of coastal geomorphology (39\%). The states with the highest national production were: MG (21.6\%), SP (20.5\%), and RJ and PR both at $16 \%$. Together these states accumulated $74 \%$ of the production in Geomorphology published in Brazil. However, during this period there was a substantial dilution of production by state, as well as by institutions. One reason may have been the increase in post-graduation courses, leading to the emergence of new centers producing knowledge in Geomorphology. At the international level, the main themes published were: coastal $(39 \%)$, river $(17.4 \%)$ and slope processes $(13 \%)$. The most productive states were SP and CE both publishing $26 \%$ of the total, followed by RS (17.4\%), and RJ and PR both at $13 \%$. The global participation of Brazil in the geomorphological production in the period was $1.0 \%$ (De Oliveira and Salgado, 2013).

Between 2011-2015, the most productive themes in geomorphological production in the national context were as follows: fluvial geomorphology (20.3\%), regional evolution of relief (19.8\%), and slope processes (19.3\%). Countrywide, the states with the highest production in Geomorphology were: SP (28\%), MG (26\%), PR (21.3\%), and RJ (15.6\%). Meanwhile, internationally, the themes with the highest production were: the regional evolution of relief $(25.6 \%)$, glacial $(18.6 \%)$, slope processes $(16.3 \%)$, fluvial (14\%), and coastal (6\%). The highest production was from the same states: SP (39.5\%), MG (35\%), RJ (21\%), and PR (9.3\%). Brazil's participation in global geomorphological production in the period was $1.4 \%$ (Salgado and Limoeiro, 2017).

In short, scientific production in Geomorphology has increased significantly in Brazil in recent years, with a concomitant expansion of knowledge-producing centers in the field. However, the Center-South of Brazil (SP, RJ, MG, and PR) shows a hegemony in scientific production; research topics have been consolidating over time. Thus, the prominent areas are fluvial geomorphology, slope processes, coastal and glacial geomorphology, and in recent years the increased participation of themes related to the evolution of the relief. It is worth emphasizing that a large part of the scientific production related to the subject of slope processes probably includes the previously denominated interface of pedo-geomorphology.

Geomorphology production has increased at the national level, but production remains stable on the international scene, with participation below $2 \%$. It is evident that the sample of journals evaluated was small. Also, many other journals publish geomorphological data, for example, Journal of South American Earth Sciences, Catena, Hydrological Processes, and the Journal of Hydrology, to list a few.

Finally, the Southeast (SP, RJ, and MG) is the leading producer of knowledge in Geomorphology. However, as previously verified, in some of these centers, Physical Geography has a small impact on the programs' H-index (e.g., UFMG, UNESP-PP, UFU, and UFF). On the other hand, the production in Geomorphology related to the postgraduate study evaluated in this study shows that the region is the largest producer (Table 2), and in this region, there is also a more significant impact on the $\mathrm{H}$-index. Therefore, future studies should incorporate the evaluation of the impact that Brazilian Geomorphological production has on postgraduate programs, as well as on science at an international level.

\section{Production characteristics of Pedology}

Soil studies still have a remarkable participation and impact in postgraduation in Geography. When Gregory et al. (2002) discuss the restructuring of Physical Geography, the field of soils and their contribution is included with Biogeography, and both have little impact in the area. It was evidenced by the authors that Geomorphology is the main branch of Physical Geography. In the case of Brazil, soil studies are relevant within Geography.

It is interesting to briefly recall the recent history of Soil Science (Soil Geography and Pedology). In the 1950s, after World War II, soil studies were directed to agriculture and food production. During this period, extensive surveys of soils and natural resources were also on the global agenda. In the 1970s, soil studies were primarily related to environmental impacts, especially soil degradation, erosion, loss of fertility, pollution, and the transfer of contaminants to areas beyond farmed areas.

In the 1990s, two themes emerged: sustainability and climate change. In the former, the soil still played an essential role in the sustainability of humanity on Earth. However, due to climate change, the 
atmospheric sciences began to receive more investments and prestige in this scenario. Thus, there was a reduction in the formation of soil scientists and pedologists. Additionally, the success of previous research that led to the belief that erosion and soil management were closed issues.

From the late 2000s onwards, soil returned to the global agenda with the original themes (e.g., soil erosion, food management, and production) and new demands such as biofuel production, energy, the reduction of greenhouse gas emissions and carbon capture and storage (Hartemink, 2008; Hartemink and Mcbratney, 2008). It is in this context that the themes and perspectives of soil studies in postgraduate studies in Geography will be evaluated.

Figure 4 shows the diversity of keywords used as soil survey indexes, as well as terms in study titles. Some of them are highlighted to contextualize the studies being evaluated. Also, some of the papers in the H-index will be cited to refer to the given keyword or term. The micromorphology proposed in the 1970 s by Kubiëna is a method for investigating the microscopic arrangement of components (e.g., voids, cutans, and others) of the soil matrix through a thin slide (Birkeland, 1999). Studies using this procedure are common in investigations of soil genesis and pedological processes (Bardy et al., 2008; Paisani et al., 2013) (Figure 3).

Soils classified as Latossolos, Ferrasols, or Oxisols are the most studied (Figure 3), bearing in mind that these pedological structures cover almost $60 \%$ of the national territory (Melfi and Pedro, 1977). In addition, due to their physical-hydric characteristics (relief, depth, structure, water retention, and others), they are widely used for agricultural activities. Thus, studies related to the management, conservation or problems of degradation of the quality of these soils are frequent (Brito et al., 2005; Sant'anna Moreira Pais et al., 2011).

The transformation of podzols and spodosols is more common in the Amazon region (Do Nascimento et al., 2008) (Figure 3). The other pedological processes identified were: a) the development of the microstructure of Oxisols (Reatto et al., 2009); b) the pedological transformations of soils in Restinga environments (Coelho et al., 2010). Studies of transformations in latosolic B horizons in B textures (Latosol /Acrisol pedological system), common in the states of Paraná and São Paulo, were not identified in the present study. However, the use of heavy minerals was applied to identify the provenance of pedological cover in Caiuá sandstone (Gasparetto and Dos Santos, 2005).

Studies on soil erosion are still among the most frequent in Geography postgraduate programs (Figure 3). However, the erosion studies in the H-index were diversified: a) a review and methodological proposals (Guerra, 2011); b) the application of prediction models of soil erosion and runoff or the identification of susceptibility to erosion using geotechnologies (Oliveira et al., 2007; Da Silva et al., 2013; Nunes et al., 2013); c) the monitoring of soil erosion in experimental plots (Júnior et al., 2008; Thomaz, 2009; Thomaz and Vestena, 2012), and d) path erosion in protected areas (Pinto et al., 2008) . 


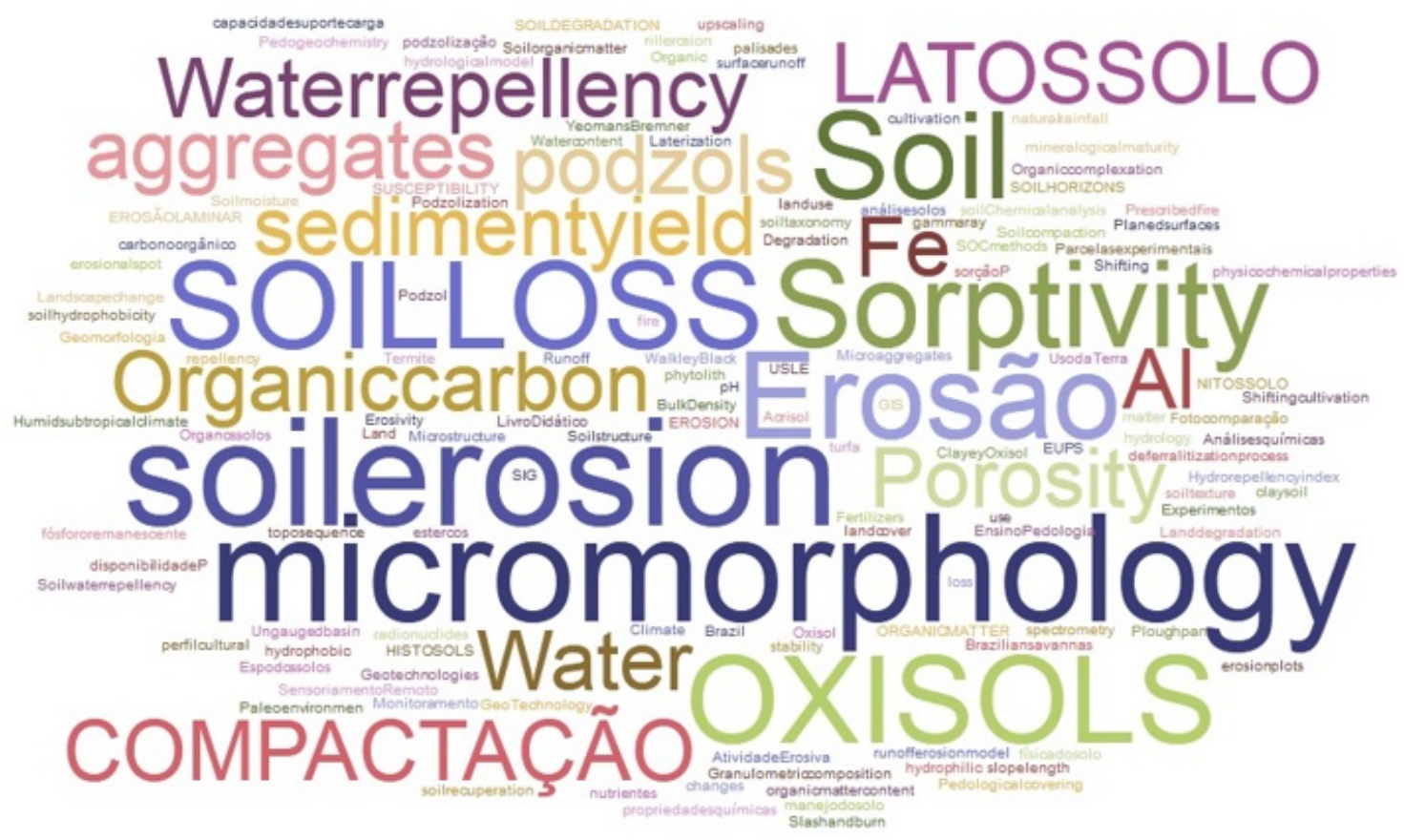

Figure 3. Keywords in soil surveys

Studies related to carbon in the soil and organic matter were more closely related to methods of determination, organic soil processes and the role of carbon in the soil in relation to soil fertility (Pereira et al., 2006; Bardy et al., 2008; Gilvani Ebeling et al., 2008). No studies on the role of soil in the carbon capture and storage were identified.

Soil water repellency or hydrophobicity is a natural process that prevents or hampers the wetting of aggregates (Debano and Krammes, 1966; Debano, 2000). This is a renowned theme in Soil Science and Hydrology, but studies of tropical soils are more recent (Mataix-Solera et al., 2011). In recent years there has been an increase in the study of the hydrophobic process in tropical soils under two conditions. The first studies soils in natural conditions searching for characteristics of the organic compounds and texture that cause repellency and, therefore, the reduction of water entry in the soil (e.g. infiltration) or even increases in aggregate stability (Vogelmann et al., 2010; Vogelmann, Reichert, Prevedello, Awe, et al., 2013; Vogelmann, Reichert, Prevedello, Consensa, et al., 2013). The second investigates the effect of fire on physical and chemical soil conditions, including hydrophobia (Thomaz et al., 2014).

The previous analysis, based on keywords and terms in the title, converge on the following Pedology research areas (Figure 4): soil erosion (30.6\%); origin (22.2\%), physicochemical and soil chemistry $(16.7 \%)$, soil physics $(11.1 \%)$ and teaching at only $2.8 \%$. When considering studies related to physics, chemistry, and soil physical-chemistry, the value is $44.4 \%$ of the total work. Pedology articles were well distributed between basic and applied research. That is, there is no purely pragmatic or utilitarian approach in Pedology studies in postgraduate programs. At times, studies in Physical Geography are perceived as purely applied studies or problem-solving. Finally, there are practically no studies focused on the teaching of Pedology and Geography of Soils, as well as on the history and epistemology of these areas of knowledge. 


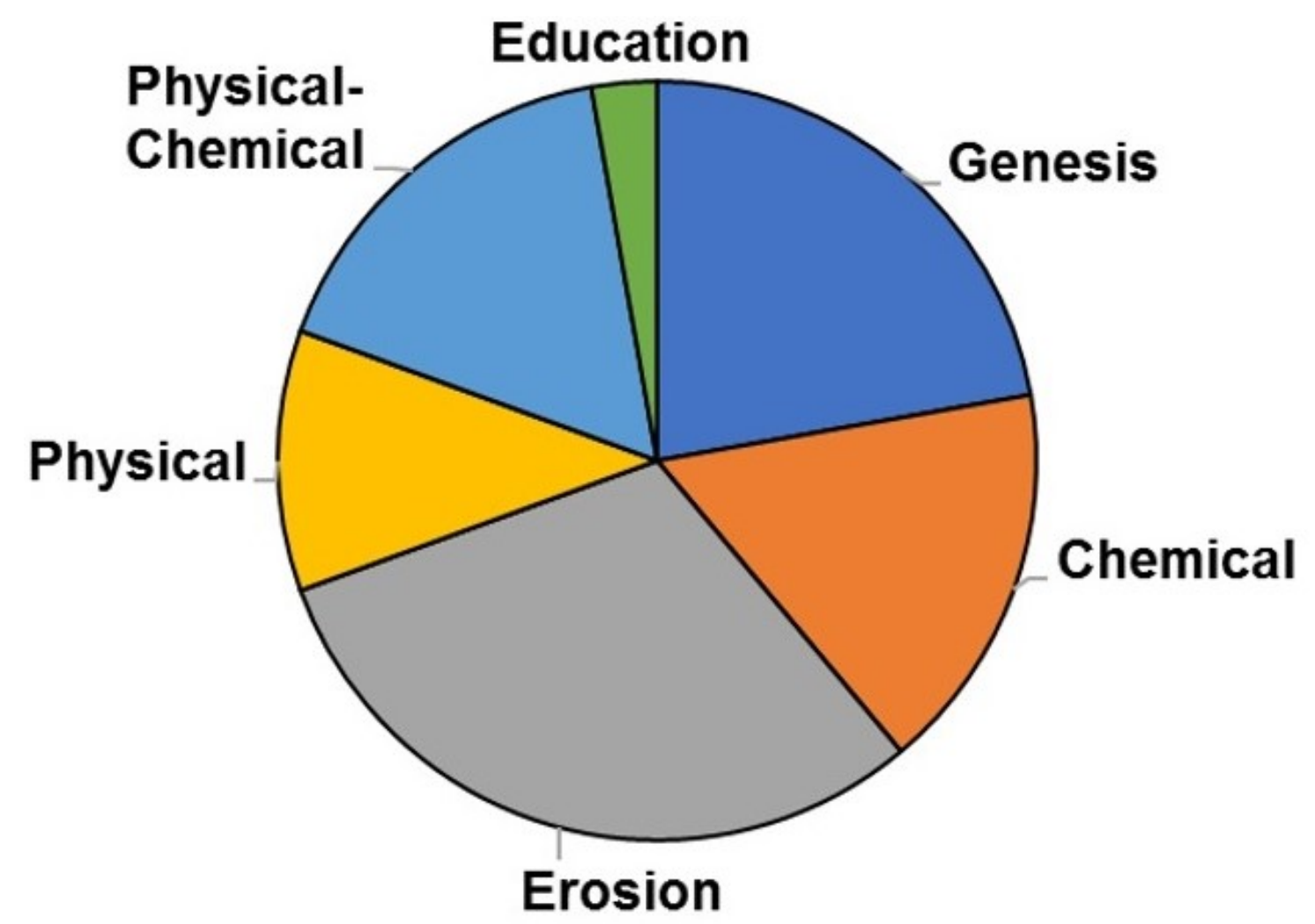

Figure 4. Subjects published in pedology

\section{Perspectives of the area of Geomorphology and Pedology in Postgraduate Geography}

To speak of the perspectives of two areas of knowledge related to Environmental Sciences, Earth Sciences, Sustainability Science and others, on a planet facing profound global environmental changes, seems to be a waste of time since the scientific and social contributions of both are evident. However, the opportunities and risks of these areas in postgraduate studies in Geography are discussed below.

The International Association of Geomorphology held a meeting bringing together various committees under its coordination. The commissions and study groups involved were: 1) the Anthropocene Geomorphology Group; 2) Geo-archeology, and 3) Geomorphology and Society. The objectives of these groups plainly demonstrate a concern with the dynamics of geomorphological landscapes and contemporary human actions. In reality, the community recognizes the Anthropocene period (Human Age on Earth), which marks the strong human influence on environmental processes. Thus, many natural bio-geochemical processes are superimposed or even supplanted by processes dynamized by contemporary society (Monastersky, 2015a). Also, if the policy of the International Geographical Union in its various commissions is examined, there is a focus on sustainability, natural hazards, social and environmental vulnerability, global changes, and similar issues.

The British Society of Geomorphology (Tooth and Viles, S.D) indicated ten reasons for the importance of Geomorphology. Six of them are related to the long evolution time of the terrestrial relief, because the landscapes are: 1) sculpted by mass movement; 2) sculpturing processes are influenced by different factors; 3) processes operate on different scales; 4) terrestrial landscapes are dynamic; 5) this dynamic is often complicated, and 6) landscapes are archives of the past. The remaining four reasons are related to the contemporary period, namely: 7) landscapes are influenced by global environmental change; 8) human activities are influencing the dynamics of landscapes; 9) land-based landscapes are becoming more dangerous, and 10) successful landscape management depends on geomorphological knowledge (Tooth and Viles, S.D). Several studies carried out by Brazilian Geomorphology are aligned with these themes. 
Added to these reasons, Progress in Physical Geography published a special edition on the future of Geomorphology (Church, 2010; Keylock, 2010), along with the SAGE Handbook of Geomorphology 's(Gregory and Goudie, 2011) excellent review of science's development in the search for understanding the evolution of relief forms, surface terrestrial processes, and their applications. Both papers provide a thematic balance of opportunities and risks in the future of Geomorphology.

In Pedology, the perspectives are also very positive. For example, in 2015, the United Nations (UN) instituted the International Year of Soils. In turn, the International Union of Soil Sciences has been carrying out activities related to the International Soil Decade (2015-2024). The International Geographical Union recently established an Agricultural Geography and Land Engineering commission (IGU Commission C16.39), whose objective is to foster research and practices that ensure the sustainability of agricultural systems. Besides this, other UGI commissions have the soil as a research focus: land degradation and desertification and the sustainability of rural systems.

In Brazil, PronaSolos was launched to resume multiscale pedological surveys and respective interpretations. The program was stimulated by the launch of the International Year of Soils in 2015 and will take several steps and is expected to be completed in 30 years (Polidoro et al., 2016). For the authors, there were discontinuities the surveying and interpretation of soils in Brazil. Therefore, the main consequence nowadays is the scarcity of courses and professionals specialized in the area of soils (pedologists) (Polidoro et al., 2016).

As noted above, soils are on the agenda in the twenty-first century as an essential component of the biosphere. However, the main threats to soil functionality include erosion, compaction, acidification, contamination, sealing, salinization, and the loss of organic carbon. The FAO (United Nations Food and Agriculture Organization) has conducted a global assessment of the four major threats to soil quality. In Brazil, the four main threats indicated were erosion; change in organic carbon; salinization and sodification, and nutritional imbalance (Montanarella et al., 2016).

The interaction between society and the soil causes the above problems. In the Anthropocene period, it is possible to think in terms of global soil changes, as the process of anthropogenesis (pedogenesis by human action) accelerates the transformations of the soils. The chief contemporary transformations in soils over a short time scale ( et al., 2004). However, for Richter (2007), at the present time, soils have gone from being bodies transformed by natural processes (Jenny, 1941), to bodies transformed by historical-cultural processes. Thus, few terrestrial landscapes on Earth escape the influence of anthropogenesis.

In conclusion, humanity is faced with a paradox: soils are under threat, and at the same time, the soil is fundamental to the sustainability of human life on Earth. Below, are listed some research opportunities in soils (pedogeomorphology), themes in which a knowledge of soils is fundamental: 1) in a world in economic development and population growth (an estimated 9 billion in 2050), food production is central to local and global food security (Godfray et al., 2010; Govers et al., 2017) ; 2) various soil issues are fundamental to the global future of agriculture (Pretty et al., 2010; Rickson et al., $2015)$; 3) soils have strong interaction with climate change (Paustian et al., 2016) ; 4) soil carbon dynamics are key to climate change mitigation (e.g., carbon capture and storage) (Roose et al., $\quad 2005$; Hartemink and Mcsweeney, 2014) ; 5) soil erosion and physical-chemical changes cause local and off-site effects mainly impacting on soil quality and water resources (e.g. transfer of nutrients and contaminants) (Pretty et al., 2010; Montanarella et al., 2016); 6) forest fires tend to increase in a climate change scenario, ire influences the dynamics of terrestrial ecosystems, as well as the soil system (Bowman et al., 2009; Scott, 2009; Santín and Doerr, 2016); and 7) mankind has been transforming soils and terrestrial landscapes, which is a new frontier of pedology to be explored (Richter, 2007; Ellis et al., 2013; Monastersky, 2015b) . These themes are an essential agenda for the field of pedogeomorphology in the twenty-first century.

Despite the immense challenges or opportunities in pedogeomorphology, there are also dangers that threaten the scientific contribution coming from postgraduate Geography, some of which are given below in the Brazilian context: a) a lack of prestige and the emptying of human and social sciences, especially Bachelor's degrees. Society is becoming increasingly pragmatic, and the areas considered as technological and scientific are more valued. This may be detrimental to Geography and, therefore, Pedology and Geomorphology that fall within this area of knowledge. Within Geography itself, in 
centers with a stronger social-human bias, the reduction of disciplines and teaching time in geomorphology and pedology can directly affect instruction and research in these specialties. It is possible that the training offered for these geographical specialties at the undergraduate level does not meet the techno-scientific demands necessary to face the challenges addressed above. In this sense, postgraduate studies in Geography may enable the continuity of education in those specialties. As previously discussed, the endogeny of Brazilian Geography and the expansion of Geography periodicals may pulverize and hide the knowledge produced.

A final risk to pedogeomorphology, especially to soil erosion studies, is the increase of studies applying geotechnology and modeling. Slope processes, such as water circulation, sediments, and nutrients, and soil erosion, should be investigated in the field, together with laboratory studies. The advances in geosciences and environmental sciences using computational technologies to study processes are undeniable. However, an overemphasis on modeling may be a threat to the advancement of pedogeomorphology, as well as for hydrological sciences (Sidle, 2006; Burt and Mcdonnell, 2015; Blume et al., 2016). We have had the opportunity to address this subject twice for different audiences: agronomists (Thomaz, 2013a) and geographers (Thomaz, 2013b). Our message is that modeling cannot be divorced from monitoring and field experiments. After all, it is these two procedures that support modeling, in the search for understanding of hydro-erosive processes.

In Geography, it is common to find studies of basin morphometry, mapping susceptibility to soil erosion, and applying the USLE (Universal Soil Loss Equation) to estimate soil erosion. Unfortunately, these studies offer few scientific contributions to the understanding and explanation of processes. Sidle (2006) is emphatic in stating that a generation of computer hydrologists is being formed. Understanding and explaining hydro-erosive processes are definitively based on direct field research (Sidle, 2006; Vidon, 2015). Furthermore, laboratory studies are central allies in the study of hydrological and geomorphological processes (Bennett et al., 2015; Blume et al., 2016).

Burt and Mcdonnell (2015), point out that scarce resources have led to an increased use of models, as studies in the field are more expensive and difficult to maintain for a long time. They point out that there are legions of doctoral students applying similar models; the only difference is the basin under investigation. Moreover, in general, model-based studies are weak at challenging hypotheses, and therefore, there has been little progress in the understanding of processes over the last decades. For example, currently (2010), only 10\% of field studies on flow are published in Water Resources Research , while $70 \%$ of the articles published are model-based (Burt and Mcdonnell, 2015). We believe that some of the Master's and Doctoral research in Geography suffers from this same problem.

\section{CONCLUSIONS}

The correlation of the $\mathrm{H}$-index, which is based on the impact of academic production, explains around $70 \%$ of the program score. Physical Geography has a vital participation in the composition of the H-index. However, there are regional asymmetries regarding the participation and impact of Physical Geography. In the Southeast, especially in larger universities, the impact of Physical Geography on the $\mathrm{H}$-index is lower. Currently, Physical Geography has a more significant impact on the H-index in the South region.

Scientific production in Geomorphology and Pedology is lower in the North (3.2\%) and Central-West (12.8\%) regions. The South region stands out with the highest scientific production in Geomorphology (36.2\%) and, somewhat more in Pedology (39.4\%). Taken together, Geomorphology and Pedology have published 50\% of their articles in English. However, taken alone, Geomorphology publishes $62 \%$ of its articles in Portuguese, whereas, in Pedology, 67\% of articles are published in English. Both areas mainly sought out specialist journals for dissemination. That is, publications occur, for the most part, in journals outside the field of Geography. Also, publication in high-impact Physical Geography periodicals, like Geomorphology and Catena, is more common in these areas. It is possible to consider that Geomorphology and, above all, Pedology have an international insertion in terms of scientific dissemination.

Notable studies in Geomorphology are fluvial geomorphology, slope processes, and coastal and glacial geomorphology, in recent years there has been an increase in the participation of themes related 
to the evolution of the relief. The most common areas of research in Pedology were: soil erosion $(30.6 \%)$; origin $(22.2 \%)$, physical chemistry and soil chemistry (both at $16.7 \%$ ), soil physics $(11.1 \%)$ and education at only $2.8 \%$. Studies related to physics, chemistry, and soil physical chemistry make up $44.4 \%$ of the total research. In both areas, basic and applied studies are balanced.

Finally, the opportunities presented for Geomorphology and Pedology in Postgraduate in Geography are excellent. The demand for technical-scientific knowledge in the areas of geosciences and environmental sciences are increasing, on a planet that is in the Anthropocene period. However, external threats, such as the discrediting of Human and Social Sciences and, especially, internal threats within Geography itself, with the endogeny of Brazilian Geography and Geotechnologies-Modeling may influence the development of these specialties.

\section{REFERENCES}

AGNEW, C.; SPENCER, T. Where have all the physical geographers gone? Transactions of the Institute of British Geographers, v. 24, n. 1, p. 5-9, 1999. ISSN 0020-2754.

BARDY, M. et al. Micromorphology and spectroscopic characteristics of organic matter in waterlogged podzols of the upper Amazon basin. Geoderma, v. 145, n. 3-4, p. 222-230, 2008. ISSN 00167061.

BENNETT, S. J.; ASHMORE, P.; NEUMAN, C. M. Transformative geomorphic research using laboratory experimentation. Geomorphology, v. 244, p. 1-8, 2015/09/01/ 2015. ISSN 0169-555X. Disponível em: < http://www.sciencedirect.com/science/article/pii/S0169555X14005388 >.

BIRKELAND, P. W. Soils and geomorphology. Oxford University Press, 1999. ISBN 0195033981.

BLUME, T.; VAN MEERVELD, I.; WEILER, M. The role of experimental work in hydrological sciences - insights from a community survey. Hydrological Sciences Journal， p. 1-4， 2016. ISSN 0262-66672150-3435.

BOWMAN, D. M. et al. Fire in the Earth system. Science, v. 324, n. 5926, p. 481-484, 2009. ISSN 0036-8075.

BRITO, O. R.; VENDRAME, P. R. S.; BRITO, R. M. Alterações das propriedades químicas de um Latossolo Vermelho distroférrico submetido a tratamentos com resíduos orgânicos. Semina: Ciências Agrárias, v. 26, n. 1, p. 33-39, 2005. ISSN 1676-546X.

BURT, T.; MCDONNELL, J. Whither field hydrology? The need for discovery science and outrageous hydrological hypotheses. Water Resources Research, v. 51, n. 8, p. 5919-5928, 2015. ISSN 1944-7973.

CAPES. Coordenação de aperfeiçoamento de pessoal de nível superior. Área 36 - Geografia. .

DAV-Diretoria de Avaliação. Documento de área p. 1-43, 2016.

CHURCH, M. The trajectory of geomorphology. Progress in Physical Geography, v. 34, n. 3, p. 265-286, 2010. ISSN 0309-1333.

COELHO, M. R. et al. Química e gênese de solos desenvolvidos sob vegetação de restinga no estado de São Paulo. Revista Brasileira de Ciência do Solo, v. 34, n. 6, p. 1951-1964, 2010. ISSN 0100-0683.

CONACHER, A. J.; DALRYMPLE, J. B. The nine unit landsurface model and pedogeomorphic research. Geoderma, v. 18, n. 1, p. 127-144, 1977/06/01/ 1977. ISSN 0016-7061. Disponível em: < http://www.sciencedirect.com/science/article/pii/0016706177900878 >.

CURCIO, G. R.; LIMA, V. C.; GIAROLA, N. Antropossolos: proposta de ordem (1a. aproximação). Embrapa Florestas, 2004.

DA SILVA, R. M. et al. Erosivity, surface runoff, and soil erosion estimation using GIS-coupled runoff-erosion model in the Mamuaba catchment, Brazil. Environmental monitoring and assessment, v. 185, n. 11, p. 8977-8990, 2013. ISSN 0167-6369.

DE OLIVEIRA, C. K. R.; SALGADO, A. A. R. Geomorfologia Brasileira: Panorama geral da produção nacional de alto impacto no quinquênio entre 2006-2010. Revista Brasileira de Geomorfologia, v. 14, 


\section{n. 1, 2013. ISSN 2236-5664.}

DEBANO, L. F. Water repellency in soils: a historical overview. Journal of Hydrology, v. 231-232, n. $0, \quad$ p. 4-32, 2000. ISSN 0022-1694. Disponível em: < http://www.sciencedirect.com/science/article/pii/S0022169400001803 >.

DEBANO, L. F.; KRAMMES, J. S. Water Repellent Soils and Their Relation to Wildfire Temperatures. International Association of Scientific Hydrology. Bulletin, v. 11， n. 2, p. 14-19, 1966. ISSN 0020-6024.

DO NASCIMENTO, N. et al. Podzolization as a deferralitization process: dynamics and chemistry of ground and surface waters in an Acrisol-Podzol sequence of the upper Amazon Basin. European Journal of Soil Science, v. 59, n. 5, p. 911-924, 2008. ISSN 1365-2389.

ELLIS, E. C. et al. Used planet: a global history. Proc Natl Acad Sci U S A, v. 110, n. 20, p. 7978-85, May 14 2013. ISSN 1091-6490 (Electronic) 0027-8424 (Linking). Disponível em: < http://www.ncbi.nlm.nih.gov/pubmed/23630271 >.

GASPARETTO, N. V. L.; DOS SANTOS, M. L. O emprego de minerais pesados como indicador da proveniência da cobertura pedológica do Arenito Caiuá na região Noroeste do Paraná. Pesquisas em Geociências, v. 32, n. 1, p. 63-67, 2005. ISSN 1807-9806.

GERRARD, A. J. Soil geomorphology. Springer Science \& Business Media, 1992. ISBN 0412441802 .

GILVANI EBELING, A. et al. Relação entre acidez e outros atributos químicos em solos com teores elevados de matéria orgânica. Bragantia, v. 67, n. 2, 2008. ISSN 0006-8705.

GODFRAY, H. C. et al. Food security: the challenge of feeding 9 billion people. Science, v. $327, \quad n$. 5967, p. 812-8, Feb 12 2010. ISSN 1095-9203 (Electronic)

0036-8075 (Linking). Disponível em: < http://www.ncbi.nlm.nih.gov/pubmed/20110467>.

GOVERS, G. et al. Soil conservation in the 21st century: why we need smart agricultural intensification. Soil, v. 3, n. 1, p. 45-59, 2017. ISSN 2199-398X.

GREGORY, K.; GURNELL, A. M.; PETTS, G. E. Restructuring physical geography. Transactions of the Institute of British Geographers, v. 27, n. 2, p. 136-154, 2002. ISSN 1475-5661.

GREGORY, K. J.; GOUDIE, A. S. The SAGE handbook of geomorphology. Sage Publications, 2011. ISBN 1412929059.

GUERRA, A. J. T. Experimentos e monitoramentos em erosão dos solos. Revista do Departamento de geografia, v. 16, p. 32-37, 2011. ISSN 2236-2878.

HARTEMINK, A. E. Soils are back on the global agenda. Soil Use and Management, v. 24, n. 4, p. 327-330, 2008. ISSN 0266003214752743.

HARTEMINK, A. E.; MCBRATNEY, A. A soil science renaissance. Geoderma, v. $\quad 148, \quad$ n. $\quad 2, \quad$ p. 123-129, 2008. ISSN 00167061.

HARTEMINK, A. E.; MCSWEENEY, K. Soil carbon. Springer Science \& Business Media, 2014. ISBN 339040847.

HARZING, A.-W. Publish or perish. 2007.

JENNY, H. Factors of soil formation; a sytem of quantitative pedology. 1941

JÚNIOR, J. F. P.; CRUZ, L. M.; RODRIGUES, S. C. Monitoramento de erosão laminar em diferentes usos da terra, Uberlândia-MG. Revista Sociedade \& Natureza, v. 20, n. 2, 2008. ISSN 1982-4513.

KEYLOCK, C. Introduction to special issue: The future of geomorphology: SAGE Publications Sage UK: London, England 2010.

MATAIX-SOLERA, J. et al. Fire effects on soil aggregation: A review. Earth-Science Reviews, v. 109, n. 1-2, p. 44-60, 2011. ISSN 00128252. 
MELFI, A.; PEDRO, G. Estudo geoquímico dos solos e formações superficiais do Brasil: Parte 1 Caracterização e repartição dos principais tipos de evolução pedogeoquímica. Brazilian Journal of Geology, v. 7, n. 1, p. 271-286, 1977. ISSN 2317-4692.

MENDES, J. B.; SALGADO, A. A. R. Geomorfologia latino-americana: panorama geral da produção da América Latina no início do século XXI (2001-2005). Revista Geografias, v. 4, n. 2, p. 101-108, 2008. ISSN 2237-549X.

MILNE, G. Some suggested units of classification and mapping, particularly for East African soils. 1935. ISSN 0012-8325.

MONASTERSKY, R. Anthropocene: The human age. Nature, v. 519, n. 7542, p. 144-147, 2015 a. ISSN 0028-0836.

MONASTERSKY, R. The human age. Nature, v. 519, n. 7542, p. 144, 2015b. ISSN 0028-0836.

MONTANARELLA, L. et al. World's soils are under threat. Soil, v. 2, n. 1, p. 79-82, 2016. ISSN 2199-398X.

NUNES, M. C. M. et al. Susceptibility to water erosion of soils from the municipality Salto do Céu, SW Mato Grosso state, Brazil-Brasil. Geografia, v. 38, n. 1, p. 191-206, 2013. ISSN 0100-7912.

OLIVEIRA, A. M. M. D.; PINTO, S. D. A. F.; LOMBARDI NETO, F. Caracterização de indicadores da erosão do solo em bacias hidrográficas com o suporte de geotecnologias e modelo predictivo. Estudos Geográficos: Revista Eletrônica de Geografia, v. 5, n. 1, p. 63-86, 2007. ISSN 1678-698X.

PAISANI, J. C. et al. Pedogeochemistry and micromorphology of oxisols-a basis for understanding etchplanation in the Araucárias Plateau (Southern Brazil) in the Late Quaternary. Journal of South American Earth Sciences, v. 48, p. 1-12, 2013. ISSN 0895-9811.

PAUSTIAN, K. et al. Climate-smart soils. Nature, v. 532, n. 7597, p. 49-57, Apr 7 2016. ISSN 1476-4687 (Electronic)

0028-0836 (Linking). Disponível em: < http://www.ncbi.nlm.nih.gov/pubmed/27078564 >.

PEREIRA, M. G. et al. Organic carbon determination in histosols and soil horizons with high organic matter content from Brazil. Scientia Agricola, v. 63, n. 2, p. 187-193, 2006. ISSN 0103-9016.

PIERRO, B. D. Conhecimento ilhado. Revista FAPESP, São Paulo, v. 204, p. 30-33, 2013.

PINTO, L. G. et al. Atividade erosiva em trilhas de unidades de conservação: Estudo de caso no Parque Nacional da Serra do Cipó, Minas Gerais, Brasil. e-Scientia, v. 1, n. 1, 2008. ISSN 1984-7688.

POLIDORO, J. et al. Programa Nacional de Solos do Brasil (PronaSolos). Embrapa

Solos-Documentos (INFOTECA-E), 2016. ISSN 1517-2627.

PRETTY, J. et al. The top 100 questions of importance to the future of global agriculture.

International Journal of Agricultural Sustainability, v. 8, n. 4, p. 219-236, 2010. ISSN 14735903

$1747762 X$.

REATTO, A. et al. Development and origin of the microgranular structure in Latosols of the Brazilian Central Plateau: significance of texture, mineralogy, and biological activity. Catena, v. 76, n. $2, \quad$ p. 122-134, 2009. ISSN 0341-8162.

RICHTER, D. D. Humanity's transformation of Earth's soil: Pedology's new frontier. Soil Science, 2007. ISSN 0038-075X.

RICKSON, R. J. et al. Input constraints to food production: the impact of soil degradation. Food Security, v. 7, n. 2, p. 351-364, 2015. ISSN 1876-4517

1876-4525.

ROOSE, E. J. et al. Soil erosion and carbon dynamics. CRC Press, 2005. ISBN 0203491939.

SAlGADO, A. A. R.; BIAZINI, J.; HENNIG, S. Geomorfologia Brasileira: Panorama Geral da 
Produção Nacional no Ínicio do Século XXI (2001-2005) Nota Técnica. Revista

Brasileira

de

Geomorfologia, v. 9, n. 1, 2008. ISSN 2236-5664.

SALGADO, A. A. R.; LIMOEIRO, B. F. Geomorfologia brasileira: panorama geral da produção nacional de alto impacto no quinquênio entre 2011-2015. Revista Brasileira de Geomorfologia, v. 18, n. 1, 2017. ISSN 2236-5664.

SANT'ANNA MOREIRA PAIS, P. et al. Compactação causada pelo manejo de plantas invasoras em Latossolo Vermelho-Amarelo cultivado com cafeeiros. Revista Brasileira de Ciência do Solo, v. 35, n. 6, 2011. ISSN 0100-0683.

SANTÍN, C.; DOERR, S. H. Fire effects on soils: the human dimension. Phil. Trans. R. Soc. B, v. 371, n. 1696, p. 20150171, 2016. ISSN 0962-8436.

SCOTT, A. C. Forest fire in the fossil record. Fire effects on soils and restoration strategies, p. 1-37, 2009.

SIDLE, R. C. Field observations and process understanding in hydrology: essential components in scaling. Hydrological Processes, v. 20, n. 6, p. 1439-1445, 2006. ISSN 0885-6087

1099-1085.

THOMAZ, E. L. The influence of traditional steep land agricultural practices on runoff and soil loss. Agriculture, Ecosystems \& Environment, v. 130, n. 1-2, p. 23-30, 2009. ISSN 01678809.

THOMAZ, E. L. Experimentação em erosão do solo: da parcela à bacia de drenagem. III Reunião Paranaense de Ciência do Solo. Londrina: IAPAR, v. 1, n. $\quad 3, \quad$ p. 1-6, 2013a. ISSN 978-85-88184-45-9.

THOMAZ, E. L. Experimentação, monitoramento e tratamento de dados como fundamento à modelagem em geografia física. XV Simpósio Brasileiro de Geografia Física Aplicada, v. 1, $2013 b$.

THOMAZ, E. L.; ANTONELI, V.; DOERR, S. H. Effects of fire on the physicochemical properties of soil in a slash-and-burn agriculture. Catena, v. 122, p. 209-215, 2014. ISSN 03418162.

THOMAZ, E. L.; VESTENA, L. R. Measurement of runoff and soil loss from two differently sized plots in a subtropical environment (Brazil). Earth Surface Processes and Landforms, v. 37, n. 4, p. 363-373, 2012. ISSN 01979337.

TOOTH, S.; VILES, H. V. 10 reasons why Geomorphology is important. British Society for Geomorphology (www.geomorphology.org.uk registered charity 1054260). p. 1-17, $\quad$ S.D. Disponível em: < http://geomorphology.org.uk/sites/default/files/10_reasons_full.pdf > .

VIDON, P. G. Field hydrologists needed: a call for young hydrologists to (re)-focus on field studies. Hydrological Processes, v. 29, n. 26, p. 5478-5480, 2015. ISSN 08856087.

VOGELMANN, E. et al. Can occurrence of soil hydrophobicity promote the increase of aggregates stability? Catena, v. 110, p. 24-31, 2013. ISSN 0341-8162.

VOGELMANN, E. et al. Threshold water content beyond which hydrophobic soils become hydrophilic: The role of soil texture and organic matter content. Geoderma, v. 209, p. 177-187, 2013. ISSN 0016-7061.

VOGELMANN, E. S. et al. Water repellency in soils of humid subtropical climate of Rio Grande do Sul, Brazil. Soil and Tillage Research, v. 110, n. 1, p. 126-133, 2010. ISSN 0167-1987. 